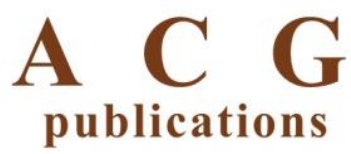

Rec. Nat. Prod. 12:1 (2018) 86-94

records of natural

products

\title{
Essential Oil Composition, Antimicrobial and Antioxidant Activities of Salvia staminea
}

\author{
Nevin Ulaş Çolak ${ }^{\oplus 1}$, Sercan Yıldırım ${ }^{\oplus *}$, Arif Bozdeveci ${ }^{\oplus 2}$, Nurettin Yayli ${ }^{\oplus 1}$, \\ Kamil Çoşkunçelebi $^{\oplus 3}$, Seda Fandaklı ${ }^{\oplus 4}$ and Ahmet Yaşar $^{\oplus 1}$ \\ ${ }^{1}$ Faculty of Pharmacy, Karadeniz Technical University, 61080, Trabzon, Türkiye \\ ${ }^{2}$ Department of Biology, Faculty of Arts and Sciences, Rize University, 53100, Rize, Türkiye \\ ${ }^{3}$ Department of Biology, Faculty of Sciences, Karadeniz Technical University, 61080, Trabzon, Türkiye \\ ${ }^{4}$ Department of Chemistry, Faculty of Sciences, Karadeniz Technical University, 61080, \\ Trabzon, Türkiye
}

(Received March 03, 2017; Revised August 18, 2017; Accepted August 22, 2017)

\begin{abstract}
Volatile constituents of the essential oil which was obtained by hydrodistillation (HD) in a Clevengertype apparatus from the air-dried Salvia staminea Montbret \& Aucher ex Bentham (Lamiaceae) collected from Bayburt (North East Part of Black Sea Reagan of Turkey), were analyzed by GC-FID and GC-MS. Additionally, volatiles for the whole part of $S$. staminea were analyzed by two different methods which are headspace (HS)-GCFID/MS and headspace solid-phase micro extraction (HS-SPME)-GC-FID/MS. As results of this study, thirty compounds from hydrodistillation, fifteen constituents from HS-SPME and two components from headspace of $S$. staminea were identified with GC-FID/MS. The major compounds identified in the essential oil, SPME and HS of S. staminea were linalyl acetate $(23.30 \%, 85.07 \%$, and $87.55 \%)$ and linalool $(22.05 \%, 9.02 \%$, and $12.44 \%)$, respectively. The antimicrobial activities of the essential oil of $S$. staminea were screened against seven microorganisms (Escherichia coli, Yersinia pseudotuberculosis, Staphylococcus aureus, Enterococcus faecalis, Bacillus cereus, Listeria monocytogenes, and Candida albican) and showed good antimicrobial activity against Gram-positive bacteria which is consistent with the literature with the other types of Salvia species. The essential oil of $S$. staminea showed good antioxidant activity with $\mathrm{IC}_{50} 60.4 \mu \mathrm{g} / \mathrm{mL}$.
\end{abstract}

Keywords: Headspace; SPME; GC-MS; PDMS; linalool; antimicrobial activity; antioxidant activity. (C) 2017 ACG Publications. All rights reserved.

\section{Introduction}

The genus Salvia L., represented by 900 species, is one of the most widespread members of the Lamiaceae and is well known its uses in folk medicine [1-3]. Recently, many medicinal plants have appeared on markets shelves as antioxidants resources for the food industry. Salvia is represented with 89 species, 50 of them are endemic to Turkey [4]. Several species such as S. officinalis L., S. fruticosa Miller, $S$. tomentosa Miller and S. virgata Jacq. are used in Anatolian folk medicine [5,6]. S. staminea is a perennial herb, distributed in Northern East of Turkey [7]. Natural compounds such as carvacrol, $\alpha$ -

\footnotetext{
* Corresponding author: E-Mail: ahmetyasar@ktu.edu.tr; Phone: +090-462-3778820 Fax: +090-462-3256717
} 
pinene, linalool and camphene were identified form other Salvia species [8]. The essential oil from the genus of Salvia had significant antioxidant activity [9].

Salvia plants are commonly known as sages which mean "to be in good health" or "to be well" [10, 11]. Sages are among the best-known classes for various biological activities [12-14]. A great number of the aromatic taxa make Lamiaceae commercially significant, owing to their aromas, infusions, tinctures, and flavors that are used as resources of herbal products [15]. The genus Salvia is known around the world for their profitable, pharmaceutical, and cultural importance, due to useful essential oils $[11,15,16]$. Sages for medical applications vary in terms of pharmacological activity. Some of them are used as nutritive tract stimulators and digestion regulators with additional antiseptic features and some of them are known for their antipyretic, analgesic, and expectorant properties [11].

The chemical composition of the essential oils of some Salvia species have been reported [17, 18]. Essential oils investigated parts of the Salvia species include flowers, leaves, stems, roots, aerial parts, and whole plants.

The target of this research was to investigate and compare the effect of extraction methods on the chemical composition variation for the volatile constituents of the essential oils, HS and SPME of $S$. staminea collected from natural source. In fact, previous works [11, 15, 17-19] on the essential oils of $S$. staminea have quite different variation with the present work for the volatile organic compounds.

\section{Materials and Methods}

\subsection{Plant Collection and Identification}

Samples of $S$. staminea were collected at the full flowering stage from Kopuz Köyü (Kopuz Village), Bayburt-Turkey (A8), alpine meadows at heights of $\sim 1740 \mathrm{~m}$ in June 2010 and identified by Prof. Dr. Kamil Coşkunçelebi. Voucher specimens were deposited in KTUB (Herbarium of the Department of Biology at Karadeniz Technical University, Turkey; Coşkunçelebi 726). Plant materials were air-dried under the shadow at room temperature for later analysis.

\subsection{Isolation of the Essential Oils}

The air-dried whole plants $(\sim 1040 \mathrm{~g})$ of $S$. staminea were hydrodistilled in a Clevenger-type apparatus using a cooling bath $\left(-15^{\circ} \mathrm{C}\right)$ system $(3 \mathrm{~h})$. The obtained oil was extracted in HPLC grade $n$ hexane $(0.5 \mathrm{~mL})$ and kept at $4^{\circ} \mathrm{C}$ in a sealed brown vial. The percentage yields of the oils from $S$. staminea calculated on a moisture-free basis were $0.15 \%(\mathrm{v} / \mathrm{w})$.

\subsection{Identification of Components by GC-MS}

For all analyses, a Shimadzu QP2010 ultra GC-MS, fitted with a PAL AOC-5000 plus auto sampler, and Shimadzu 2010 plus FID and Shimadzu Class-5000 Chromatography Workstation software was used. The gas chromatographic conditions were as followed: GC oven fitted with a RTX$5 \mathrm{M} 30 \mathrm{~m}$ capillary column $(0.25 \mathrm{~mm}$ I.D., $0.25 \mu \mathrm{m}$ film thickness, Restek, USA) with carrier gas helium at flow rate of $1.0 \mathrm{~mL} \mathrm{~min}^{-1}$, operating under an initial temperature at $60^{\circ} \mathrm{C}(2 \mathrm{~min})$ to $240^{\circ} \mathrm{C}(5$ $\min )$ at $5^{\circ} \mathrm{C} / \mathrm{min}$, with $\mathrm{He}$ as carrier gas $(1 \mathrm{~mL} / \mathrm{min})$, the temperature of the injector and detector were $250^{\circ} \mathrm{C}$ and $230^{\circ} \mathrm{C}$, respectively. The ionization voltage was $70 \mathrm{eV}$. Identification of compounds was based on a comparison of their mass spectra with standards [20-22]. Confirmation of compound identities was obtained using retention index [22]. The datum analysis was performed on a National Institute of Standards and Technology (NIST) library (Shimadzu, Kyoto, Japan) and Wiley libraries of mass spectra and literature comparison [22,23-25]. After analysis on a Restek RTX-5M column, quantification was performed as peak area using integration data.

Essential oils are a mixed combination of natural compounds. The constituents of the oils are mainly terpenes or oxygenated compounds derived from these hydrocarbons. The chemical composition of essential oils differs in each species or subspecies. The compositional studies of essential oils have been carried out extensively by using gas chromatography-mass spectrometry (GC-MS), which is based on the comparison of the relative retention times/indices and mass spectra of the specific natural 
compounds found in an essential oil [22, 26-28]. Identification of individual components was made by comparison of their retention times with those of available analytical standards ( $\alpha$-pinene, camphene, linalool, geraniol, $n$-tetradecane, $n$-pentadecane, $n$-heptadecane, and $n$-octadecane), and by computer searching, matching mass spectral data with those held in the National Institute of Standards and Technology (NIST) and Wiley libraries of mass spectra and literature comparison [22,23].

\subsection{Headspace Solid-Phase Micro Extraction}

\subsubsection{Sampling Preparation}

For SPME sampling, S. staminea puree was prepared by blending $100 \mathrm{~g}$ plant for 3 min without water in a Waring blender. The plant puree $(1 \mathrm{~g})$ was placed into a $10 \mathrm{~mL}$ headspace vial, and the flask was closed with a septum. The SPME headspace volatiles were collected using a Supelco $573482 \mathrm{~cm}$, $50 / 30 \mu \mathrm{m} \mathrm{DVB/Carboxen/PDMS} \mathrm{Stable-Flex} \mathrm{fiber} \mathrm{(precondition} \mathrm{of} \mathrm{the} \mathrm{fiber} \mathrm{at} 250{ }^{\circ} \mathrm{C}$ in the injection port of a GC for $10 \mathrm{~min}$ ) for $30 \mathrm{~min}$ (the highest concentration of aroma compounds without qualitative change of the composition; tested by $10 \mathrm{~min}$ extraction steps up to $30 \mathrm{~min}$ ). After sampling, the SPME device was placed into the injector of the GC and the GC-MS instruments through the whole GC analysis time of 62 min using RTX-5M column. The identified compounds are listed in Table I.

\subsection{Headspace Gas Chromatography-Mass Spectrometry}

The headspace gas chromatography-mass spectrometry (HS-GC-MS) analyses were carried out with use of a Shimadzu QP2010 ultra GC-MS, fitted with the Shimadzu AOC-5000 plus autosampler, and Shimadzu 2010 plus FID used in the headspace mode. Temperature and time of the headspace desorption were, respectively, $70^{\circ} \mathrm{C}$ and $15 \mathrm{~min} .0 .5 \mathrm{~mL}$ of the headspace phase was introduced on to the RTX-5M $30 \mathrm{~m}$ capillary column $(0.25 \mathrm{~mm}$ I.D., $0.25 \mu \mathrm{m}$ film thickness, Restek, USA). Helium was used as carrier gas. Gradient analysis was run using the above. The temperature of the injector was kept constant at $250^{\circ} \mathrm{C}$. The mass spectrometer was fitted with an EI source operated at $70 \mathrm{eV}$. Identification of individual compounds was based on a comparison of the obtained mass spectra of the individual chromatographic peaks with those valid for the standards and available from the National Institute of Standards and Technology (Gaithersburg, MD) software library. The identified compounds are listed in Table 1.

\subsection{Antimicrobial Activity Assessment}

Test microorganisms obtained from the Hifzissihha Institute of Refik Saydam (Ankara, Turkey) are as followings; Escherichia coli (E. coli) ATCC 25922, Yersinia pseudotuberculosis ( $Y$. pseudotuberculosis) ATCC 911, Staphylococcus aureus (S. aureus) ATCC 25923, methicillin resistant Staphylococcus aureus (MRSA), Enterococcus faecalis (E. faecalis) ATCC 29212, Listeria monocytogenes ATCC 43251, Bacillus cereus (B. cereus) 709 ROMA, Candida albicans (C. albicans) ATCC 60193 and Saccharomyces cerevisiae (S. cerevisiae) RSKK 251. Essential oil obtained by hydrodistillationfrom $S$. staminea was dissolved in acetone to prepare sample stock solutions of 38.27 $\mu \mathrm{g} / \mathrm{mL}$.

\subsection{Agar Well Diffusion Method}

Simple susceptibility screening test using agar-well diffusion method [29] as adapted earlier [30] was used. Each bacterium was suspended in Mueller Hinton (MH) (Difco, Detroit, MI) broth. The yeast like fungi was suspended in Yeast extracts broth. Then the microorganisms were diluted approximately 106 colonies forming unit (cfu) per mL. For yeast like fungi, Sabouraud Dextrose Agar (SDA) (Difco, Detriot, MI) were used. Brain Heart Infusion Agar (BHI) (Difco, Detriot, MI) was used for M. smegmatis. They were "flood-inoculated" onto the surface of MH, BHI and SD agars and then dried. Five-millimeter diameter wells were cut from the agar using a sterile cork-borer, and $50 \mu \mathrm{L}$ of the stock extract substances were delivered into the wells. The plates were incubated for $18 \mathrm{~h}$ at $35^{\circ} \mathrm{C}$. The 
Mycobacterium smegmatis was grown for 3 days on $\mathrm{BHI}$ agar plates at $35^{\circ} \mathrm{C}$ [31]. Antimicrobial activity was evaluated by measuring the zone of inhibition against the test organism. Ampicillin $(10 \mu \mathrm{g})$ was standard drug. Hexane was used as a solved control.

Table 1. Identified components in the HD, SPME, and HS of S. staminea

\begin{tabular}{|c|c|c|c|c|c|c|c|c|c|}
\hline \multirow[b]{2}{*}{ No } & \multirow[b]{2}{*}{ Compounds } & \multicolumn{2}{|c|}{$\mathrm{HD}^{\mathrm{a}}$} & \multicolumn{2}{|c|}{ SPME $^{\mathrm{b}}$} & \multicolumn{2}{|c|}{$\mathbf{H S}^{\mathrm{c}}$} & \multirow[t]{2}{*}{ Exp.RI $^{\mathrm{d}}$} & \multirow[t]{2}{*}{ Lit. RI } \\
\hline & & $\begin{array}{l}\mathbf{Q}^{\mathbf{f}} \\
(\%)\end{array}$ & $\begin{array}{c}\% \\
\text { Area }\end{array}$ & $\begin{array}{l}Q^{f} \\
(\%)\end{array}$ & $\begin{array}{c}\% \\
\text { Area }\end{array}$ & $\begin{array}{l}Q^{f} \\
(\%)\end{array}$ & $\begin{array}{c}\% \\
\text { Area }\end{array}$ & & \\
\hline 1 & Hexanal & 96 & 0.44 & & & & & 807 & $801^{33}$ \\
\hline 2 & Cyclohexanone & 98 & 1.24 & & & & & 902 & $895^{30}$ \\
\hline 3 & Myrcene & 90 & 2.01 & 95 & 0.81 & & & 992 & $997^{33}$ \\
\hline 4 & $\begin{array}{l}\text { Dehydroxy-(Z)- } \\
\text { Linalool oxide }\end{array}$ & 95 & 1.83 & & & & & 997 & $991^{33}$ \\
\hline 5 & Limonene & 95 & 0.19 & 92 & 0.26 & & & 1027 & $1029^{33}$ \\
\hline 6 & $\delta$-3-Carene & 81 & 0.21 & & & & & 1035 & $1031^{33}$ \\
\hline 7 & cis-Ocimene & 97 & 0.66 & 94 & 0.17 & & & 1042 & $1037^{33}$ \\
\hline 8 & $E$ - $\beta$-Ocimene & 95 & 1.49 & 96 & 0.22 & & & 1045 & $1050^{33}$ \\
\hline 9 & trans-Linalool oxide & & & 99 & 0.11 & & & 1076 & $1073^{33}$ \\
\hline 10 & Terpinolene & 91 & 0.17 & & & & & 1082 & $1089^{20}$ \\
\hline 11 & cis-Linalool oxide & & & 95 & 0.12 & & & 1096 & $1087^{20}$ \\
\hline 12 & Linalool & 91 & 22.05 & 98 & 9.02 & 96 & 12.44 & 1102 & $1097^{20}$ \\
\hline 13 & $\alpha$-Terpineol & 91 & 4.98 & & & & & 1193 & $1189^{20}$ \\
\hline 14 & Linalyl formate & & & 97 & 1.72 & & & 1215 & $1216^{20}$ \\
\hline 15 & Linalyl acetate & 91 & 23.30 & 90 & 85.07 & 97 & 87.55 & 1257 & $1257^{20}$ \\
\hline 16 & Geraniol & 91 & 1.04 & & & & & 1260 & $1253^{20}$ \\
\hline 17 & Geranyl Formate & 83 & 0.58 & & & & & 1287 & $1298^{20}$ \\
\hline 18 & $\alpha$-Cubebene & 98 & 2.28 & & & & & 1342 & $1351^{20}$ \\
\hline 19 & 8-Acetoxylinalool & & & 85 & 0.34 & & & 1342 & - \\
\hline 20 & $\alpha$-Terpenylacetate & & & 85 & 0.24 & & & 1355 & $1349^{20}$ \\
\hline 21 & Geranyl acetate & 95 & 1.16 & 85 & 0.25 & & & 1383 & $1379^{20}$ \\
\hline 22 & $\alpha$-Copaene & 98 & 1.61 & 94 & 0.60 & & & 1386 & $1374^{20}$ \\
\hline 23 & $\beta$-Bourbonene & & & 93 & 0.11 & & & 1395 & $1388^{20}$ \\
\hline 24 & $\beta$-Caryophyllene & 99 & 0.80 & 95 & 0.17 & & & 1411 & $1419^{20}$ \\
\hline 25 & $\alpha$-Humulene & 90 & 0.25 & & & & & 1461 & $1454^{20}$ \\
\hline 26 & Geranyl Propanoate & 90 & 1.70 & & & & & 1470 & $1478^{20}$ \\
\hline 27 & Valencene & 95 & 2.36 & & & & & 1490 & $1496^{20}$ \\
\hline 28 & $\delta$-Cadinene & 99 & 0.86 & & & & & 1523 & $1523^{20}$ \\
\hline 29 & $\alpha$-Calacorene & 89 & 0.75 & & & & & 1549 & $1546^{20}$ \\
\hline 30 & Spathulenol & 99 & 10.02 & & & & & 1585 & $1578^{20}$ \\
\hline 31 & Caryophyllene oxide & 93 & 5.45 & & & & & 1595 & $1582^{20}$ \\
\hline 32 & Sclareoloxide & 91 & 2.89 & & & & & 1903 & $1906^{23}$ \\
\hline 33 & $\beta$-Springene & 95 & 2.45 & & & & & 1920 & $1922^{22}$ \\
\hline 34 & Sclarene & 96 & 1.05 & & & & & 1986 & $1975^{20}$ \\
\hline 35 & Manoyl oxide & 99 & 0.56 & & & & & 2008 & $1998^{20}$ \\
\hline 36 & Sclareol & 85 & 4.85 & & & & & 2233 & $2223^{20}$ \\
\hline & Total & & 99.23 & & 99.21 & & 99.99 & & \\
\hline
\end{tabular}

${ }^{\mathrm{a}} \mathrm{HD}$ : Hydrodistillation, ${ }^{\mathrm{b}}$ SPME: Solid phase microextraction, ${ }^{\mathrm{c}} \mathrm{HS}$ : Head space, ${ }^{\mathrm{d}}$ Experimental RI, retention index, ${ }^{\mathrm{e}} \mathrm{LRI}$, literature retention index, ${ }^{\mathrm{f}} \mathrm{Q}$ : Quantities.

\subsection{Antioxidant Activity Assessment}

2,2-Diphenyl-2-hydrazyl picryl (DPPH) is a fast and convenient method [32-34], commonly used for detection of radical scavenging activity, evaluation of the antioxidant properties components. DPPH stable free radical can accept an electron or hydrogen radical and thereby turns into a stable diamagnetic molecule. DPPH has one electron; therefore, it has a strong absorption band at $517 \mathrm{~nm}$. Treatment with antioxidants causes to decrease the intensity of the violet DPPH absorbance stemming of DPPH. The mixtures were incubated for $30 \mathrm{~min}$ at room temperature in the dark. After incubation, 
the absorbance of the essential oil was measured at $517 \mathrm{~nm}$. Assay mixture without essential oil was used as a control. The inhibition percentage was calculated using the equation $y=a x+b$, it can be determined the concentration of sample which reduces DPPH concentration to half-dominated $\mathrm{mg} / \mathrm{mL}$. This concentration is expressed as the $\mathrm{IC}_{50}$ value. Resulting extract and ascorbic acid as a standard were prepared at different concentrations. After the samples are pipetted into tubes needed primarily sample solution onto an equal volume $(750 \mu \mathrm{L})$ solution of DPPH adding, vortex and allows incubating at room temperature for 50 minutes. At the end of that time, absorbance was read at $517 \mathrm{~nm}$ and $\mathrm{IC}_{50}$ values were calculated from the graph.

\section{Results and Discussion}

Hydrodistillation of the dried whole plant material of $S$. staminea produced light orange oil with a yield of $0.15 \%(\mathrm{v} / \mathrm{w})$. HD, SPME, and HS of $S$. staminea were investigated by GC-FID/MS and a total of 30, 15, and 2 compounds, representing $99.23 \%, 99.21 \%$ and $99.99 \%$ were identified, respectively. The identity, retention time, and the percentage composition of the HD, SPME, and HS of S. staminea are presented in Table 1.

The major constituents of the essential oil of $S$. staminea were linalyl acetate (23.30\%), linalool $(22.05 \%)$, spathulenol (10.02\%), caryophyllene oxide (5.45\%), $\alpha$-terpineol (4.89\%), sclareol (4.85\%), and sclareoloxide (2.89\%). SPME and HS GC-FID/MS analysis of $S$. staminea gave the linalyl acetate (85.07\% and $87.55 \%)$, linalool $(9.02 \%$ and $12.44 \%)$ as the main compounds, respectively. Since the linalyl acetate and linalool was the major constituent in all three methods, linalyl acetate was found to be greatest amount in HS sample. Whereas, HD of S. staminea had the linalool in the highest amount.

In the essential oil of $S$. staminea,thirty components were classified as 7 monoterpenes, 6 monoterpenoids, 8 sesquiterpenes, 3 diterpenes, 2 sesquiterpenoids, 2 diterpenoids, and 2 others type compounds. SPME analysis of S. staminea revealed 5 monoterpenes, 7 monoterpenoids, and 3 sesquiterpene type of compounds, whereas HS analysis of $S$. staminea gave only 2 monoterpenoids.

Table 2. The chemical class distribution of the HD, SPME and HS components of S. staminea

\begin{tabular}{|c|c|c|c|c|c|c|}
\hline \multirow{2}{*}{ Compound class } & \multicolumn{2}{|c|}{ HD } & \multicolumn{2}{|c|}{ SPME } & \multicolumn{2}{|c|}{ HS } \\
\hline & Area $\%$ & $\mathrm{NC}^{\mathrm{a}}$ & Area $\%$ & $\mathrm{NC}^{\mathrm{a}}$ & Area\% & $\mathrm{NC}^{\mathrm{a}}$ \\
\hline Monoterpenes & 4.73 & 6 & 1.57 & 5 & - & - \\
\hline Monoterpenoids & 58.47 & 8 & 96.76 & 7 & 99.99 & 2 \\
\hline Sesquiterpenes & 8.91 & 7 & 0.88 & 3 & - & - \\
\hline Sesquiterpenoids & 18.36 & 3 & - & - & - & - \\
\hline Diterpene & 3.50 & 2 & - & - & - & - \\
\hline Diterpenoids & 5.41 & 2 & - & - & - & - \\
\hline Others & 1.68 & 2 & - & - & - & - \\
\hline The common compounds & 45.35 & 2 & 94.09 & 2 & 99.99 & 2 \\
\hline
\end{tabular}

SPME rendered possible the analysis of all the plant material under the same conditions even though its comprehensive composition. This is not always possible with other extraction methods. Using a nonpolar poly (dimethylsiloxane) (PDMS) phase, many terpenoid hydrocarbons, together with alcohols, cyclic ethers, and esters, were extracted. The ease of use and the high resolution of the chromatographic profiles obtained make HS-SPME well suited to the rapid characterization of the main components of the volatile fraction of plants [35].

The chemical class of the volatile constituents from HD, SPME and HS of S. staminea grouped into seven classes which are named monoterpenes (4.73\% HD, 1.57\% SPME), monoterpenoids (58.47\% HD, 96.76\% SPME, 99.99\% HS), sesquiterpenes (8.91\% HD, 0.88\% SPME), sesquiterpenoids (18.36\% $\mathrm{HD})$, diterpenes $(3.50 \% \mathrm{HD})$, diterpenoids $(5.41 \% \mathrm{HD})$, and others $(1.68 \% \mathrm{HD})$ were given in Table 2 , respectively.

The major compounds in the classified group (monoterpenes, monoterpenoids, sesquiterpenes, sesquiterpenoids, diterpenes, diterpenoids, and others) of volatiles for the HD, SPME and HS of $S$. 
staminea listed in Table 3. Myrcene, linalyl acetate, valencene, spathulenol, $\beta$-springene, sclareol, and cyclohexanone in HD, myrcene, linalyl acetate, and $E$-caryophyllene in SPME and linalyl acetate in HS were found to be major compounds.

Table 3. The major components in the chemical class distribution of the HD, SPME, and HS constituents of S. staminea

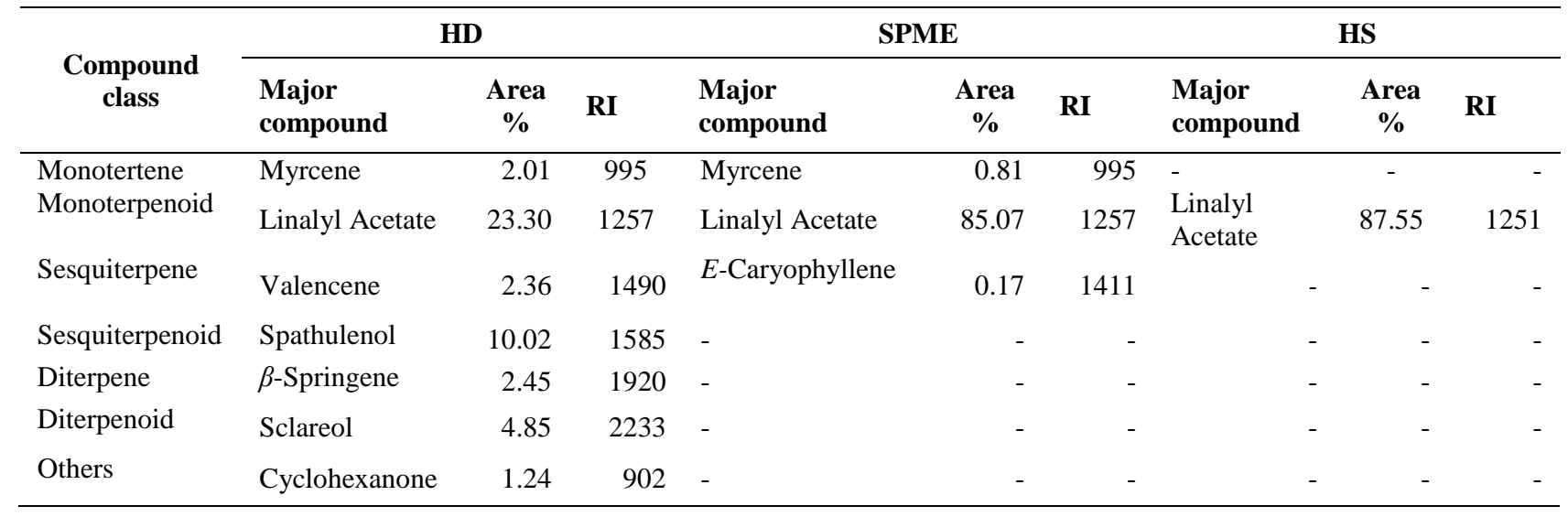

In the previous studies, the volatile composition and antimicrobial activity of the essential oils of $S$. stamenia collected from the botanical garden have been studied $[11,15]$ and the major components of the essential oil for S.staminea were mentioned to be $\alpha$-pinene, camphene, $\beta$-pinene, limonene, eucalyptol and $\beta$-chamigrene $[11,15]$.

In the literature, volatile organic compounds from dried aerial parts (flowers, leafs, leafy branches and stems) of forty-five Salvia species have been identified using thermal desorption technique coupled to GC-MS (TD-GC-MS) and sesquiterpene hydrocarbons $(0.90-45.02 \%)$ were recorded to be the major class of volatile constituents and chemical composition [17]. The essential oil S. staminea growing in Iran from different populations, had been reported and $\beta$-caryophyllene (15.5-19.62 \%), ledol (2.5-18.81 \%), pentamethyl-1, 3 cyclopantadien (5-12.69 \%), p-cresol (9.3-12.91\%) and pentamethylcyclopentadien (4.66-12.29\%) were mentioned to be major constituents. [18].

Various experimental techniques were used for the isolation and identification of volatile organic compounds of the plants which are; low-temperature TLC-MS of the essential oils from five different Salvia species (S. lavandulifolia, S. staminea, S. hians, S. triloba, and S. nemorosa) [36,37]; the volatile compounds of five different Salvia species (S. lavandulifolia, S. staminea, S. hians, S. triloba, and $S$. nemorosa) using four different techniques (head-space, vapor distilation, and accelerated solvent extractions) [11]; the essential oils of five different Salvia species (S. lavandulifolia, S. staminea, S. hians, S. triloba, and S. nemorosa) using low temperature planar chromatographydensitometry attached with gas chromatography [38] have been reported. Also, the essential oils of twenty species of Salvia natural or cultivated in Poland have been investigated by headspace GC-MS and the major compounds of the volatile fraction of these Salvia species were reported as $\alpha$-pinene, camphene, $\beta$-pinene, thujol, camphor, $\beta$-chamigrene, and cadina-3,9-diene. Thujenone was mentioned to be as chemotaxonomic marker in S. staminea. In the literature, $\beta$-caryophyllene (15.5-19.62 \%) and $\alpha$ copaene $(7.0 \%)$ were major constituent of the esential oil of S. staminea [18]. In our case, they were minor compounds which were less than $1.61 \%$. Also, thujenone mentioned to be as chemotaxonomic marker for the $S$. staminea [11], however it was not observed it in this work.

In the present study, different chemical composition of the plant that was harvested from the natural environment was obtained. Essential oil composition and antioxidant activity of various extracts of $S$. staminea were reported [18]. When the structures of the most abundant components reported in literature for the HD, SPME, and HS of S. staminea were examined, quite different variation was observed.

S. staminea plant contains linalyl acetate which is the main component of the plant. However, the other types of Salvia plants grown in Turkey do not contain any linalyl acetate. Additionally, Salvia plants except for S. staminea comprise a very small amount of linalool which is the second main component of these plants. Linalool contents of $S$. candidissima Vahl., S. chionanthaand $S$. 
potentillifolia were $0.31 \%, 0.42 \%$, and, $0.43 \%$, respectively. The main volatile component of $S$. staminea and $S$. candidissi Vahl. plants, collected from the pharmacy garden, is $\beta$-pinene [18]. The major components of $S$. staminea were germacrene D $(36.3 \%)$ followed by hexahydrofarnesylacetone $(11.2 \%)$ and $\alpha$-copaene $(7.0 \%)$ [18].

Our study showed that chemical differences of the composition of the HD, SPME, and HS could be attributed to the geographical source, time of collection of the plant and the specific climate there. In addition, stress-induced alteration of the chemical structure, since the plant grows in the botanical gardens away from the natural environment, may cause these differences [37-40]. The reason for the variation in essential oil contents can be caused by the ecosystem of the plants, the solvent used during extraction, and harvest season. However, separation of plants from their natural environment causes stress factors, which can be biotic or abiotic, and give rise to losses in quality and quantity of the product. Furthermore, the content of the plant may change. Physical conditions (snow, the wind, and mechanical effects) and chemical conditions (such as pesticides, etc.) can be effective on the content according to the level of adaptation of the plants. Light, due to the formation mechanism of photosynthesis, can produce stress effects on the plant directly, resulting in reduced production of photosynthesis of carbohydrates produced by the plant which directly reduces the number of nutrients and hence causes a slowing of plant growth.

The antimicrobial activities of the essential oils of $S$. staminea were tested against seven bacterai in vitro using the agar-well diffusion method [33, 34, 39] with the microorganisms listed in Table 4. Only the essential oil of $S$. staminea showed good antibacterial activity against Gram-positive bacteria and the fungi with $6 \mathrm{~mm}$ to $23 \mathrm{~mm}$ inhibition zone, respectively.

Table 4. Antimicrobial activity of the essential oil of S. staminea

\begin{tabular}{llccccccc}
\hline Sample & $\begin{array}{l}\text { Stoc. } \\
(\mu \mathrm{g} / \mathrm{ml})\end{array}$ & \multicolumn{7}{c}{ Microorganisms and Inhibition zone (mm) } \\
& & $\mathrm{Ec}$ & $\mathrm{Yp}$ & $\mathrm{Sa}$ & $\mathrm{Ef}$ & $\mathrm{Bc}$ & $\mathrm{Li}$ & $\mathrm{Ca}$ \\
\hline Essential oil & 38.27 & - & - & 20 & 15 & 23 & - & 6 \\
Ampicillin & 10 & 10 & 18 & 35 & 10 & 15 & 10 & - \\
\hline Ec: Escherichia coli ATCC 25922, Yp: Yersinia pseudotuberculosis ATCC 911, Sa: Staphylococcus aureus ATCC 25923, Ef: \\
Enterococcus faecalis ATCC 29212, Bc: Bacillus cereus & 702 Roma, Li: Listeria monocytogenes ATCC 43251, Ca: Candida albicans ATCC \\
60193, (-): no activity.
\end{tabular}

The essential oil of S. steminea was found to exhibit significant antioxidant activity by scavenging DPPH. The order of $\mathrm{IC}_{50}$ values for DPPH for the essential oil was found $60.4 \mu \mathrm{g} / \mathrm{mL}$ references to ascorbic acid $(28.2 \mu \mathrm{g} / \mathrm{mL})[33,34,38]$.

\section{Acknowledgments}

This work was financially supported by Research Fund of Karadeniz Technical University, Turkey (BAP-1238).

\section{ORCID}

Nevin Ulaş Çolak: 0000-0003-3200-6688

Sercan Yildırım: 0000-0003-2457-8248

Arif Bozdeveci: 0000-0002-0729-9143

Nurettin Yayli: 0000-0003-4174-3014

Kamil Coskuncelebi: 0000-0001-5713-6628

Seda Fandakl1: 0000-0002-8199-3336

Ahmet Yaşar: $\underline{0000-0002-5487-1536}$ 


\section{References}

[1] R. D. Gibbs (1974). Chemotaxonomy of Flowering Plants, Montreal: McGill-Queen’s University Press; 3, $1405-1406$

[2] A. Ulubelen and G. Topcu (1992). Abietane diterpenoids from Salvia pomifera, Phytochemistry. 31, 39493951.

[3] J. B. Walker, K. J. Sytsma, J. Treutlein and M. Wink (2004). Salvia (Lamiaceae) is not monophyletic: implications for the systematics, radiation, and ecological specializations of Salvia and tribe Mentheae, Am. J. Bot. 91, 1115-1125.

[4] K. H. C. Başer (2002). Aromatic biodiversity among the flowering plant taxa of Turkey, Pure Appl. Chem. 74, 527-545.

[5] F. Celep and A. Kahraman (2012). Salvia L. In: A. Güner, S. Aslan, T. Ekim, M. Vural and, M.T. Babaç (eds.) Türkiye Bitkileri Listesi, (Damarlı Bitkiler). Nezahat Gökyiğit Botanik Bahçesi ve Flora Araştırmaları Derneği Yayını, İstanbul.

[6] N. Zeybek and U. Zeybek (1994). Farmasotik Botanik, Ege Universitesi Basımevi, İzmir

[7] P. H. Davis (1982). Flora of Turkey and the East Aegean Islands, Edinburgh: Edinburgh University Press; 7, 400-461.

[8] H. J. D. Dorman, S. G. Deans and R. C. Noble (1995). Evaluation in vitro of plants essential oils as natural antioxidants, J. Essent. Oil Res.7, 645-651.

[9] I. Zupko, J. Hohmann, D. Redei, G. Falkay, G. Janicsak and I. Mathe (2001). Antioxidant activity of leaves of Salvia species in enzyme-dependent and enzyme-independent systems of lipid peroxidation and their phenolic constituents, Planta Med. 67, 366-368.

[10] M. Roberts (1986). Margaret Roberts' Book of Herbs: The Medicinal and Culinary Uses of Herbs in South Africa. Southern Book Publishers, National Book Printers, Goodwood, Cape.

[11] J. Rzepa, Ł. Wojtal, D. Staszek, G. Grygierczyk, K. Labe, M. Hajnos, T. Kowalska, and M. Waksmundzka-Hajnos (2009). Fingerprint of selected Salvia species by HS-GC-MS analysis of their volatile fraction, J. Chromatogr. Sci. 47, 575-580.

[12] H. M. Chang, K. P. Cheng, T. F. Choang, H. F. Chow, K. Y. Chui, P. M. Hon, F. W. L. Tan, Y. Yang, Z. P. Zhong, C. M. Lee, H. L. Sham, F. C. Chan, Y. X. Cui and H. N. C. Wong (1990). Structure elucidation and total synthesis of new tanshinones isolated from Salvia miltiorrhiza Bunge (Danshen), J. Org. Chem. $\mathbf{5 5}, 3537-3543$.

[13] A. Ulubelen (2000). "Terpenoids of the Genus" in SAGE the Genus Salvia, Spiridon E. Knitzios, Ed.; Harwood Academic Publishers, Amsterdam, 55-68.

[14] G. Topçu, U. Kolak, M. Öztürk, M. Boğa, S. D. Hatipoğlu, F. Bahadori, B. Culhaoğlu and T. Dirmenci (2013). Investigation of anticholinesterase activity of a series of Salvia extracts and the constituents of Salvia staminea, The Nat. Prod. J. 3, 3-9.

[15] M. Sajewicz, J. Rzepa, M. Hajnos, Ł. Wojtal, D. Staszek, T. Kowalska and M. Waksmundzka-Hajnos (2009). GC-MS study of the performance of different techniques for isolating the volatile fraction from sage (Salvia L.) species, and comparison of seasonal differences in the composition of this fraction, Acta Chromatogr. 21, 453-471.

[16] B. M. Lawrence (1992). Chemical components of Labiatae oils and their exploitation. In: Advances in Labiatae Science. Eds, R.M Hariey and T. Reynolds. Royal Botanical Gardens, Kew, UK, 399-436.

[17] S. D. Hatipoglu, N. Zorlu, T. Dirmenci, A. C. Goren, T. Ozturk and G. Topcu (2016). Determination of volatile organic compounds in fourty five Salvia species by thermal desorption-GC-MS technique, Rec. Nat. Prod. 10, 659-700.

[18] P. Salehi, A. Sonboli and S. E. Moghadam (2013). Essential oil composition and antioxidant activity of Salvia staminea Benth. extracts, JEOBP, 16, 582-587.

[19] S. Samadi and B. Fattahi (2014). Study of compounds of essential oil diversity of some populations of Salvia staminea Monthr et Auch. ex Benth in Iran, Anal. Chem. Lett. 4, $50-56$.

[20] S. J. Wagstaff (1992). A phylogenetic interpretation of pollen morphology in tribe Meraheae (Labiatae). In: Advances in Labiatae Science. Eds, R.M Hariey and T. Reynolds. Royal Botanical Gardens, Kew, UK, $113-124$.

[21] M. Ahmed, I. P. Ting and R. W. Scora (1994). Leaf oil composition of Salvia hispanica L. from three geographical areas, J. Essent. Oil Res. 6, 223-228.

[22] R. P. Adams (2004). Identification of Essential Oil Components by Gas Chromatography-Mass Spectroscopy. Allured Carol Stream, Illinois, USA.

[23] N. Yaylı, A. Yaşar, C. Güleç, A. Usta, S. Kolaylı, K. Coşkunçelebi and Ş. Karaoğlu (2005). Composition and antimicrobial activity of essential oils from Centaurea sessilis and Centaurea armena, Phytochemistry 66, 1741-1745.

[24] National Institute of Standards and Technology (2008). NIST\EPA 365\NIH Mass Spectral Library, Version 2.0.

[25] M. Güllüce, H. Özer, Ö. Barış, D. Daferera, F. Şahin and M. Polissiou (2006). Chemical composition of the essential oil of Salvia aethiopis L., Turk. J. Biol. 30, 231-233.

[26] G. Flamini, K. Ertugrul, P. L. Cioni, I. Morelli, H. Dural and Y. Bagc1 (2002). Volatile constituents of two endemic Centaurea species from Turkey: C. pseudoscabiosa subsp. pseudoscabiosa and C. hadimensis, Biochem. System Ecol. 30, 953-959. 
[27] H. Dural, Y. Bagc1, K. Ertugrul, H. Demirelma, G. Flamini, P. L. Cioni and I. Morelli (2003). Essential oil composition of two endemic Centaurea species from Turkey, Centaurea mucronifera and Centaurea chrysantha, collected in the same habitat, Biochem. System Ecol. 31, 1417-1425.

[28] H. D. Skaltsa, C. Demetzos, D. Lazari and M. Sokovic (2003). Essential oil analysis and antimicrobial activity of eight Stachys species from Greece, Phytochemistry 64, 743-752.

[29] C. Perez, M. Pauli and P. Bazerque (1990). An antibiotic assay by the well agar method, Acta Biol. Med. Exp. 15, 113-115.

[30] I. Ahmad, Z. Mehmood and F. Mohammed (1998). Screening of some Indian medicinal plants for their antimicrobial properties, J. Ethnopharmacol. 62, 183-193.

[31] G. L. Woods, B. A. Brown-Elliott, E. P. Desmond, G. S. Hall, L. Heifets, G. E. Pfyffer, J. C. Ridderhof, R. J. Wallace, N. C. Warren and F. G. Witebsky (2003). Susceptibility testing of mycobacteria, nocardiae, and other aerobic actinomycetes; Approved Standard. NCCLS document M24-A, 23 (18).

[32] J. A. Pino, J. Mesa, Y. Muñoz, M. P. Martí and R. Marbot (2005). Volatile components from mango (Mangifera indica L.) cultivars, J. Agric. Food Chem. 53, 2213-2223.

[33] H. A. Diri (2006). Characterization of essential compositions and determination of antioxidant activity of Salvia candidissima Vahl. Master Thesis, Muğla University, Institute of Science and Technology, Muğla.

[34] I. Kivrak (2006). Chemical composition of the essential oil of Salvia potentillifolia Boiss \& Heldr. ex Bentham and determination of antioxidation properties. Master Thesis, Muğla University, Institute of Science and Technology, Muğla.

[35] E. Psillakis and N. Kalogerakis (2001). Solid-phase microextraction versus single-drop microextraction for the analysis of nitro aromatic explosives in water samples, J. Chromatogr. A. 938, 113-120.

[36] S. Mieczyslaw, W. Lukasz, H. Michal, W. H., Monika and K. Teresa (2010). Low-temperature TLC- MS of essential oils from five different sage (Salvia) species, J. Planar Chromatogr-Mod. TLC. 23, 270-276.

[37] S. Mieczyslaw, W. Lukasz, S. Dorota, H. Michal, W. H., Monika and K. Teresa (2010). Low temperature planar chromatography-densitometry and gas chromatography of essential oils from different sage (Salvia) species, J. Liq. Chromatogr. Relat. Technol. 33, 936-947.

[38] X. Li, H. Jiang, F. Liu, J. Cai, T. Dai, W. Cao and D. Jiang (2013). Induction of chilling tolerance in wheat during germination by pre-soaking seed with nitric oxide and gibberellin, Plant Growth Regul.71, 31-40.

[39] İ. Eröz Poyraz, G. Akalın Ciftçi and N. Öztürk (2016). Phenolic contents, in vitro antioxidant and cytotoxicity activities of Salvia aethiopis L. and S. ceratophylla L. (Lamiaceae). Rec. Nat. Prod. 11:4 345-355

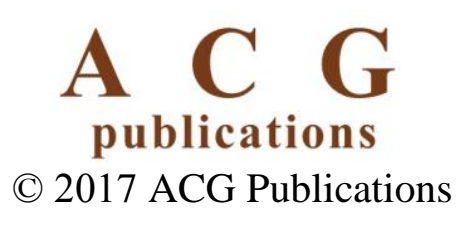

